\title{
IAMJ
}

INTERNATIONAL

AYURVEDIC

MEDICAL JOURNAL

Review Article

ISSN: 2320-5091

Impact Factor: 6.719

\section{CONCEPTUAL STUDY OF THE EFFICACY OF LODHRA WITH HONEY GEL IN UPAPLUTA YONIYAPAD (VAGINAL CANDIDIASIS IN PREGNANCY)}

\author{
Seema Gholap ${ }^{1}$, Sumit Kumbhare ${ }^{2}$ \\ ${ }^{1}$ Associated Professor, Department of Prasutitantra Evam Stree-Rog, Bharati Vidyapeeth Deemed to be University, \\ College of Ayurveda, Pune, Maharashtra, India \\ ${ }^{2}$ PG Scholar, Department of Prasutitantra Evam Stree-Rog, Bharati Vidyapeeth Deemed to be University, College \\ of Ayurveda, Pune, Maharashtra, India
}

Corresponding Author: sumitkumbhare10@gmail.com

https://doi.org/10.46607/iamj1009022021

(Published online: February 2021)

Open Access

(C) International Ayurvedic Medical Journal, India 2021

Article Received: 04/01/2021 - Peer Reviewed: 24/01/2021 - Accepted for Publication: 27/01/2021

(A) Check for updates

\section{ABSTRACT}

Introduction: The pregnant women are more prone to vaginal infection like vulvovaginitis, which presents a challenge for doctor today. Pregnant state produces several normal and expected changes in all the maternal organ systems, from which vaginal candidiasis is one. Vaginal secretion changes during pregnancy mainly vaginal PH. Vaginal secretions during pregnancy falls from a $\mathrm{pH}$ of greater than 7 (an alkaline $\mathrm{pH}$ ) to 4 or 5 (an acid $\mathrm{pH}$ ). Due to this change in vaginal $\mathrm{pH}$ candida albicans growth occurs. In pregnancy, there is higher oestrogen level and higher glycogen level which helps in growth of candida. According to Ayurveda if woman during pregnancy take Kapha aggravating Ahar and Vihar excessively and suppresses the urges of vomiting and respiration, the vitiated $V a y u$ carries Kapha to genital tract affect the same and vaginal white discharge is seen in pregnant woman due to Kapha and Vata; This is known as "Upapluta Yonivyapad". Lodhra has Kashay Ras which help in decreasing Kapha Dosha and Madhu has Tridoshahar property which cures Upapluta Yonivyapad. Aim: The present study is aimed to assess the efficacy of Lodhra with Madhu gel in Upapluta Yonivyapad. Material and Methods: The present study is done, to analyze the effect of Lodhra and Madhu gel in Upapluta Yonivyapad. Study is performed with help of various previous research paper published, from various authentic Ayurvedic and Modern books as well as Samhitas. Conclusion: In pregnancy, due to Kapha and Vata there is a change in vaginal pH and vaginal white 
discharge; Also, there is high estrogen level which cause vaginal candida. Lodhra has property of Kaphahar, analgesic, anti-inflammatory, antibacterial, antihelminthic. Madhu is one of the five elixirs of immortality (panchamrut) and has properties like: Tridoshahar, antiseptic, antimicrobial, antiallergic, anti-inflammatory. Thus, it balances the Dosha and result in decrease (vaginal candida) Upapluta Yonivyapad. Thus, Lodhra and Madhu gel can work effectively in Upapluta Yonivyapad.

Keywords: Candidiasis, Lodhra, Upapluta Yoviyapad, Vulvovaginitis

\section{INTRODUCTION}

Pregnancy is a natural event which is experienced by every woman in her life. During pregnancy there is imbalance in Dosha, Dhatu and Mala which causes various disorder in pregnancy. In pregnancy there is altered immunological state in which women is prone for many diseases, metabolic as well as infective origin.

Wilkinson described Vaginal Candidiasis for the first time in 1849. In women vaginal secretions are under the influence of hormonal changes. Vaginal flora which contain aerobic and anaerobic microorganisms responsible for maintaining of vaginal $\mathrm{pH}$. This $\mathrm{pH}$ has defence mechanism against microorganism growth in female genital tract.

Sometimes, vaginitis is accompanied by pelvic inflammatory diseases, post-operative infections, abnormal cervical cytology, chronic cervicitis, and urinary tract infection ${ }^{1}$. Most specialists believe that $90 \%$ of cases of vaginitis are secondary to bacterial vaginosis, vulvovaginal candidiasis, and trichomoniasis ${ }^{2}$.

According to Ayurveda if woman during pregnancy take Kapha aggravating Ahar and Vihar excessively and suppresses the urges of vomiting and respiration, the vitiated Vayu carries Kapha to genital tract and affects the same, because of this white mucus discharge piercing pain occurs due to invasive disorders of Kapha and Vata. This is known as "Upapluta Yonivyapad". The treatment mentioned by Acharay Charak is Lodhra, Priyangu and Madhuka for Upapluta Yonivyapad in the form of varti ${ }^{3}$.

Upapluta Yonivyapad is one among the 20 Yonivyapads described by Acharyas. On the basis of the textual description Upapluta Yonivyapad can be compared to vulvovaginitis during pregnancy.

Charak has mentioned Upapluta Yonivyapad in Charak Samhita Chikitsa Sthan 30/21,22.
Ashtang Sangraha has mentioned Upapluta Yonivyapad in Ashtang Sangraha Uttartantra 38/49.

Ashtang Hruday has mentioned Upapluta Yonivyapad in Ashtang Hruday Uttartantra 33/48,49

In pregnancy, there is high level of estrogen and altered $\mathrm{pH}$ which leads to grow candida rapidly. Conditions like GDM, obesity, unhygienic condition are responsible for various infection including vaginal candidiasis. Surgical procedure like cervical encirclage also cause vaginal infection (foreign body reaction). Modern science has good treatment for vaginal candidiasis (local and oral). But its safety in pregnancy is doubtful, and they are little expensive as well as they don't prevent recurrence. In addition, vaginitis may occur as the result of non-infectious causes, such as vaginal atrophy, allergies, and chemical irritation ${ }^{4}$.

It is accepted by everyone that Ayurveda is an ancient most treatise in medical world. In Samhitas there is description of Yonivyapad from which Upapluta Yonivyapad is one described by Acharyas. On the basis of the textual description Upapluta Yonivyapad can be compared to candidiasis during pregnancy.

Aim: To study the concept of Upapluta Yonivyapad (vaginal candidiasis during pregnancy)

\section{Objectives-}

- Conceptual study of Upapluta Yonivyapad (vaginal candidiasis during pregnancy)

- Conceptual study of Lodhra and Madhu.

Previous Work Done -

1. A Clinical Study to Evaluate the Efficacy of Sallakyadi Sneha Pichu In Garbhini Upapluta

2. Efficacy of Dhatakyadi Taila Yonipichu On Upapluta In Garbhini - A Clinical Study.

3. Effect of Pancha-Valkala Choorna In Upapluta Yoni-Vyapada. 
4. A Clinical Study on Upapluta Yonivyapad With Special Reference to Vulvovaginitis During Pregnancy and Its Management with Panchavalkaladi Varti.

5. Study on Upapluta Yonivyapada With Special Reference to Vulvovaginitis During Pregnancy and Its Management with Panchavalkaladi Formulation

6. A Clinical Study on Upapluta Yonivyapada With Special Reference Vulvovaginitis During Pregnancy and Its Management with Dhatakyadi Yoga

7. Effect of Uttara-Basti In Upapluta Yoni-Vyapada.

8. Effect of Gokshuradi Choorna In Upapluta YoniVyapada.

9. Efficacy of Guduchyadi gel in vaginal candidiasis during pregnancy.

10. Efficacy of Jati Patrak gel on Upapluta Yonivyapad.

Materials and Method - For the conceptual study classical books like Samhita, modern books, published articles as well as internet source has been referred. Collection of the material was carried out in concise manner from these sources.

\section{Lodhra:}

Latin name: Symplocos racemose

Family: Symplocaceae

\section{Synonyms: -}

Sanskrit: Rodhra, Paittaka Lodhra, sabara Lodhra. English: Symplocos bark

Hindi: Lodha

\section{Morphology:-}

- Lodhra is evergreen medium size tree with height of 6-6.8 m

- Lodhra leaves - 3 to 4 inches long, circular or oval shaped, leaf stalk is small and it's velvety to touch.

- Lodhra flower - flowering generally occurs in month of November and continuous till February. Flowers are cream colored, small in size and mostly found in cluster.

- Lodhra fruit - purple blackish in color and are 1.5 inches long, leathery

- Lodhra seed - Its fruit contain 1 to 3 seeds.

- Lodhra bark - it is light brown in color. a) Macroscopic: Mature stem bark occurs in channelled or curved pieces, few fiat pieces also occur in thickness upto $1 \mathrm{~cm}$, outer surface uneven and rough due to fissures and cracks, greyish brown to grey externally, pale to whitish brown internally, fracture short and granular in cortical region and somewhat fibrous in inner region, taste, astringent and feebly bitter.

b) Microscopic: Transverse section of mature bark shows a wide cork of thin-walled, rectangular cells arranged in radial rows, cork cambium 1-3 layered, secondary cortex consists of thin-walled, oval and tangentially elongated parenchymatous cells towards outer side and rounded cells towards inner side, a number of stone cells, in singles or in groups present, scattered throughout the region having highly thickened walls with distinct pits, prismatic and cluster crystals of calcium oxalate, and starch grains, mostly simple present in a number of cortical cells, secondary phloem wide consisting of sieve elements, phloem parenchyma, phloem fibres and stone cells, phloem parenchyma thin-walled, oval to rectangular, containing prismatic crystals of calcium oxalate scattered in phloem parenchyma.

Powder - Greyish-brown, under microscope shows fragments of cork, stone cells, fibres, prismatic and cluster crystals of calcium oxalate and starch grains.

\section{Rasa Panchak:-}

- Rasa: Kashaya

- Guna: Laghu, Rukshya.

- Veerya: Katu

- Vipak: Sheeta.

- Part used: Twak.

- Chemical constituents: Loturine, Colloturine, Loturidine

- Pharamacological action: Analgesic, Anti-inflammatory, Antibacterial, Antihelminthic

- Therapeutic uses: Shotha, Atisara, Netraroga, Raktapitta, Pradara

\section{Madhu:}

Latin name: Mal depuratum

Family: Apidae 
Synonyms: Madhu, Makshika, Madhvika, Kshaudra, Saragha, Makshikvanta, Vanta, Bhrugavanta, Pushpararasodbhava .

Honey has antibacterial property. Liquid honey does not spoil; because of its high sugar content it kills bacteria by plasmolysis. Natural air borne yeast cannot become active in it, as moisture content is low. Natural honey varies from $14 \%$ to $18 \%$ in moisture content. As long as the moisture content remains under $18 \%$ virtually no organism can successfully multiply to significant amount in honey.

According to Bhavprakash, honey is of eight types. Makshika, Bhramara, Kshaudra Pauttika, Chatra, Aarghya, Oudalaka and Dala Madhu. Their qualities are as follows:-

- Makshika honey is collected by large honeybees. It is Laghu (lighter than Kshaudra), Ruksha (Dry), It's useful in Kamla (Jaundise), Arsha (Piles), Kshata (Phithis), Kasa (Cough) diseases. It is the best and especially beneficial in diseases like Asthma.

- Bhramara honey is collected by large bees. This honey is Guru (heavy - not easily digested) because of its Picchila (Slimy) and Ati Swadu (excessively sweet) properties. It is Rakta Pitta shamak.

- Kshaudra honey is collected by medium sized honeybees. It is Sheeth (Cold), Laghu (light - easy to digest) and Lekhana (Anti-obesive). It is the best and especially beneficial in diseases like Prameha (Diabetes).

- Pauttika honey is collected by very large bees from the nectar of poisonous flowers. It is Ruksha (Dry), Ushna (Hot), it increases Vata, Rakta and Pitta, and this is also Chedana (liquefaction). It produces burning sensation in the chest. It is also a sedative and reduces fat. It is useful in disease like Diabetes and Dysuria.

- Chatra honey is Madhura (Sweet after digestion), Guru (heavy), Sheetha (Cold) and Picchila (Slimy). It cures bleeding disorders, leukoderma (Shwitra), urethritic discharges and worm infestations.

- Arghya honey is beneficial for eyes, eliminates vitiated Kapha and Pitta Dosha, Kashaya
(Astringent in taste), Katu Vipaka (Pungent after digestion), Balya (Strengthening).

- Oudalaka honey is useful in skin diseases and helps in modulation of voice. It is Kashaya (Astringent) and Amla Rasa (Sour), Katu Vipaka (Pungent after digestion).

- Dala honey is Ruksha (Dry). It mitigates vomiting and diabetes mellitus.

According to Acharya Sushruta, some actions of fresh and aged honey are very much opposite to each other. Nava Madhu (Fresh honey) has Bruhana guna (Nourishing the body) but it does not eliminate vitiated Kapha Dosha much and is a laxative. Puran Madhu (Aged honey) is Grahi (Anti diarrheal), reduces fat and obesity ${ }^{6}$ Ayurveda explains another special quality of honey. Honey is known as "Yogavahi" - since it has a quality of penetrating the deepest tissue. When honey is used with other herbal preparations it enhances the medicinal qualities of those preparations and also helps them to reach the deeper tissues.

\section{Properties According to Modern Science}

Experiments and studies on honey have shown that honey is antiseptic, antimicrobial, antipyretic, anti-inflammatory, anti-allergen, antitoxic, sedative, laxative, anti-anemic, antioxidant, healing and cleansing (external and internal), moisturizing and blood-purifying. It promotes rehydration, easily digestible, stimulates immunity, and is beneficial for all types of skin diseases.

Rasa Panchak:-

- Rasa: Madhura, Kashaya

- Guna: Guru, Ruksha

- Veerya: Sheeta

- Vipak: Katu

- Karma: Tridoshahar, Kaphapittahar

- Chemical constituents: Acetic acid, butanoic acid, formic acid, citric acid, succinic, lactic, malic, Gluconic acid, pyroglutamic acid and aromatic acids are found.

- Pharamacological action: Antiseptic, Antimicrobial, Antiallergic, Anti-inflammatory. 


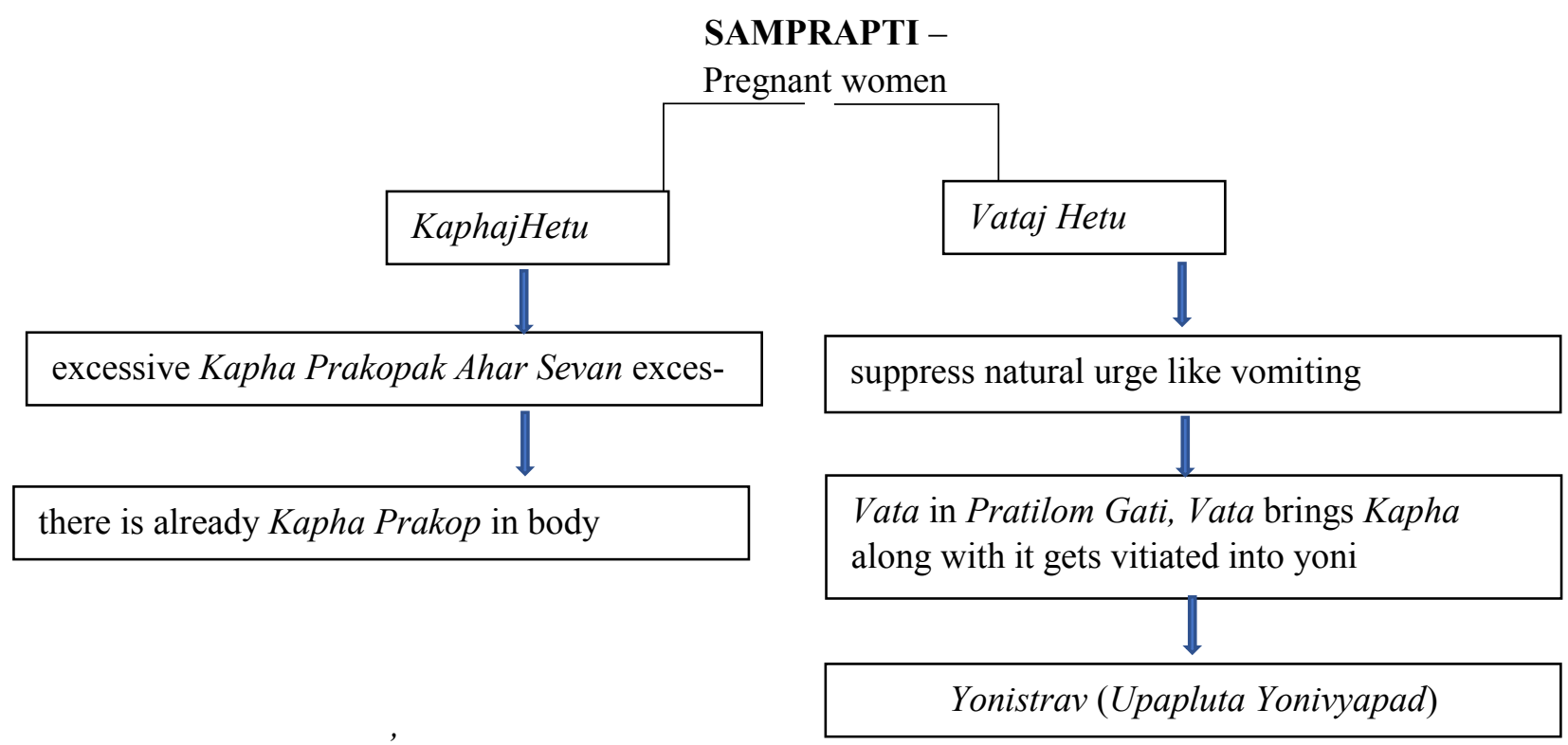

\section{DISCUSSION}

Microbial infections of the vagina among pregnant women are serious issues and may lead to many medical emergencies such as preterm labor, amniotic fluid infection, premature rupture of fetal membranes, and low birth weight of neonate. Pregnant women have twofold increase in the prevalence of vaginal microorganisms' colonization than compared to non-pregnant women. Increased levels of circulating oestrogens and deposition of glycogen and other substrates in vagina during pregnancy influences the association. Thus, proper identification and treatment will reduce the risk of preterm birth and its consequences. In pregnant women there is a Kapha prakopa which results in Upapluta Yonivyapad. Lodhra is Kaphahar, has properties like analgesic, anti-inflammatory, antibacterial, antihelminthic thus reducing the symptoms related to upapluta and preventing various medical emergencies. Madhu is Tridoshahara as well as has properties like antiseptic, antimicrobial, anti-allergic, anti-inflammatory. Thus, Lodhra with honey gel can work effectively in Upapluta Yonivyapad (vaginal candidiasis during pregnancy) and thus can cure the signs and symptoms.

\section{CONCLUSION}

Study is going on at Bharati Ayurveda Hospital. Result will be published on completion of study.

\section{REFERENCES}

1. Novak BJ. Novak's Gynecology. 14th ed. Philadelphia: Lippincott Williams \& Wilkins; 2007. P. 545

2. Sobel JD. Epidemiology and pathogenesis of recurrent vulvovaginal Candidacies. American Journal of Obstetrics and Gynecology. 1985, 152(7):924-935.

3. Charaka Samhita with English Translation base on Chakrapani Datta's Ayurveda Deepika by Vaidya Bhagwan Das and DR. R.K. Sharma, Chaukhamba Sanskrit series, Varanasi $6^{\text {th }}$ edition, 1999

4. Soll DR, Galask RU, Isley SH, Rao TV, Stone DE, Hicks J, et al. Switching of C. albicans during successive episodes of recurrent vaginitis. Journal of Clinical Microbiology. 1989; 27(4):681-690

5. Shastri Brahmashankar, commentator, Vidyotini Hindi commentary, in Bhavprakash, 6th edition, Varanasi, Chaukhamba Sanskrit Sansthan 1984 Verse no 6 pg no 788

6. Jadavaji Trikamji Acharya, Editor, Susruta Samhita, 7th edition, Varanasi, Chaukhamba Orientalia, 2002; 207-8. Verse 45/132-142.

\section{Source of Support: Nil \\ Conflict of Interest: None Declared}

How to cite this URL: Seema Gholap \& Sumit Kumbhare: Conceptual Study Of The Efficacy Of Lodhra With Honey Gel In Upapluta Yoniyapad (Vaginal Candidiasis In Pregnancy). International Ayurvedic Medical Journal \{online\} 2021 \{cited February, 2021\} Available from: http://www.iamj.in/posts/images/upload/391 395.pdf 